\title{
Biomarkers on Sediments in a Highly Saline Aquatic Ecosystem: Case of the Moknine Continental Sebkha (Eastern Tunisia)
}

\section{Raja Chairi}

Georesearch Laboratory, Ecopark BorjCedria, Tunisia

*Corresponding author: Raja Chairi, Georesearch Laboratory, Ecopark BorjCedria, Tunisia, Tel: +216 79325 122; E-mail: chairi_ra@yahoo.fr

Received Date: May 5, 2017; Accepted Date: October 15, 2018; Published Date: October 23, 2018

Copyright: (C) 2018 Raja Chairi. This is an open-access article distributed under the terms of the Creative Commons Attribution License, which permits unrestricted use, distribution, and reproduction in any medium, provided the original author and source are credited.

\begin{abstract}
Surficial sediments from 18 sites throughout Moknine sebkha, one of the largest urbanized sebkha in the sahel of tunisia, were analyzed for biomarkers ( $n$-alkanes, hopanes and steranes) to track the origin of organic inputs. A distinct spatial distribution of aliphatic hydrocarbons in sediments was observed in Moknine sebkha which subdivide this environment in two area. The submerged area is characterized by high concentration of OC $1 \%-4.9 \%$, EOM $2 \%-49 \% \mathrm{CO}$, aliphatic hydrocarbons $1350 \mu \mathrm{g} . \mathrm{kg}-1$ to $3700 \mu \mathrm{g} . \mathrm{kg}-1$ sediment dry weight. Emerged area is characterized by low concentration (OC<1\%, EOM $<12 \% \mathrm{OC}$ and $\mathrm{F} 1<1200 \mu \mathrm{g} . \mathrm{kg}^{-1}$ sediment dry weight. Several ratios (e.g. CPI, ACL, NAR, TAR, Pr/Ph...) were used to evaluate the possible sources of terrestrial-lacustrine inputs of these hydrocarbons in the sediments. The various origins of aliphatic hydrocarbons were generally biogenic, including both terrigenous and cyanobacteria. The source of contamination is not petroleum. The predominance of biogenic in combination with petrogenic hydrocarbons was indicated by the biomarkers. $\alpha \beta$ trishomohopane $\mathrm{C} 33$ indicate an anthropogenic contribution (wastewater) in two stations (treated domestic wastewater (ssm1-2) and untreate industrial wastewater ssm6). The presence of biogenic hopanes $(17 \beta(H), 21 \beta(H)$-hopanes) indicate the biogenic origin of organic matter in the Moknine sebkha. The UCM not indicate petrogenic origin but high activities of bacteria in highly saline system.
\end{abstract}

Keywords: Sebkha; Sediment; Biomarkers; Hydrocarbons; Index

\section{Introduction}

biomarkers are the indicators of depositional environments arises from the fact that certain types of compounds are associated with organisms or plants that grow in specific types of depositional environments [1-3]. Lake sediments are the excellent archives of past environmental changes. Evaluating the stored environmental information in the sediments depends on the knowledge about the ecosystem and the understanding of the present day lake response to environmental variability [2]. Knowing the processes driving the terrestrial input is essential to understand for instance carbon deposition and nutrient input, which are linked to climate through weathering and transport processes. On the other hand, understanding the anthropogenic impact is key to assess the environmental status of a lake today and in recent history.

The moknine sebkha (Tunisia) is a higly saline aquatic system located in the sahel of Tunisia. Many study are taken in this system: sedimentology (4-6), organic geochemistry [4-7] of sediment and geochemical organic and mineral of the water [8]. All studies shows that this system is oligotrophy and is subdivided in micro area governed by the topography, the climatology and the hydrology. Our aim was to establish possible links between organic matter input, climatic processes and evolution of the system. To evaluate the contribution of $\mathrm{OM}$ and $\mathrm{OM}$ origin, natural terrestrial, biogenic and anthropogenic inputs were assessed using biomarkers such as nalkanes, hopanes and steranes new parameter index (e.g. NAR, TMD, ACL...).

"NAR" (Natural n-alkane ratio) is proposed [9] to evaluate the contribution of terrestrial inputs of hydrocarbons in the sediments. It's close to zero in petroleum hydrocarbons and is close to 1 in marine or higher terrestrial plants.

$$
N A R=\left[\frac{\sum \operatorname{odd}(C 19-32)-2 \sum \text { even }(C 20-32)}{\sum(C 19-32)}\right]
$$

TMD : TMD (Terrigenous Marine Discriminant) : (n-C25+ n$\mathrm{C} 27+\mathrm{n}-\mathrm{C} 29+\mathrm{n}-\mathrm{C} 31+\mathrm{n}-\mathrm{C} 33 / \quad(\mathrm{nC} 15+\mathrm{n}-\mathrm{C} 17+\mathrm{n}-\mathrm{C} 19+\mathrm{n}-\mathrm{C} 21+\mathrm{n}-\mathrm{C} 23)$, TMD (Terrestrial Marine Discriminant) is indicated from terrestrial and marine sources with a value 1 . A value $>$ a dominant terrestrial input, whereas a value $<0.5$ confirm dominant marine contribution [10-12].

The average chain length (ACL) is another method applied to study the source of $n$-alkanes in environment based on the concentration of the odd-carbon-numbers of the n-alkanes of higher plant [13].

ACL values of leaf wax components are calculated from the following equations

$A C L=\left(\frac{(25 C 25+27 C 27+29 C 29+31 C 31+33 C 33)}{C 25+C 27+C 31+C 33}\right)$

ACL could reflect past changes in vegetation. In the warmer climates, plants produce a longer-chain of n-alkanes [15]. The ACL is very useful in the identification of the environmental changes of a particulate ecosystem. The ACL of plant lipids preserved in various sediments (lake, ocean, soil...) has been widely adopted to reconstruct past changes in climate and environment during the late Quaternary [16-22].

Therefore, the material maturity can be numerically assessed using the carbon preference index (CPI) [23-25] as follow:

$C P I: \quad(1 / 2)\left[\frac{\sum C 25-C 33}{\sum C 24-C 32}+\frac{\sum C 25-C 33}{\sum C 26-C 34}\right]$ 
Values of CPI will be $>1$ since odd number n-alkanes dominate, but as maturity increases, the odd number predominance is reduced and the index approaches 1.

The presence of mature and/or petrogenic terrestrial input can also be monitored using hopanes and steranes [25]. These compounds are two additional classes of semi volatile organic compounds which are derived from the cell membranes of prokaryotes [26,27] and eukaryotes [28] respectively, and are common constituents of crude oil $[29,30]$ show that hopane and sterane have a distinct configuration such as derived from petrogenic (crude oil and derived products) or biogenic sources (vascular plants, algae, bacteria). $\beta \beta$-hopane configuration is biogenic; $\alpha \beta$-hopane configuration is thermodynamically stable and dominates in petroleum. These compounds are resistant to chemical, photochemical and microbial degradation [29,31], hopanes and steranes have been used as signature or marker compounds to help identify sources of organic matter in lake sediments [32-34], the extent of biodegradation [35], and as tracers of vehicle exhaust in the atmosphere (given their specificity to lubricating oils used in diesel and gasoline engines) [36-38]. Information regarding hopanes and steranes in the Great Lakes is scarce.

Sterane biomarkers likely represent the diagenetic product from biomolecules in microorganisms, with hopane representing molecular fossils from algae [39]. Hopanes are derived from cell membranes of prokaryotes (heterotrophic bacteria and also phototrophic cyanobacteria), and they are characterized by numerous maturitysensitive stereoisomers [26]. Steranes are derived from eukaryotic cell membrane sterols, mainly from algae and higher plants. Both hopanes and steranes are commonly used as a fingerprint of petrogenic input to the environment [40].

In Hypersaline lakes anoxic conditions are developed if saline deep water is covered with water of lower density. Sediment that were deposited under these conditions often contain high relative concentrations of gammacerane, which is a biomarker generally associated with water column stratification [41,42]. To evaluate environment conditions hopane index will be calculated by ratio (gammacerane/C31hopane).

In general, C27 and C29 steranes are indicative of an algae and higher plant source of organic matter. The ratio of C27/C29-steranes $>1$ specifies the predominance of organic matter input from marine algae, while $<1$ indicates a preferential higher plant input [43].

\section{Material and Methods}

\section{Study area}

The Moknine sabkha, between Mahdia (Southeast) and Moknine (Northwest), is separated from the Mediterranean Sea by a $4-6 \mathrm{~km}$ wide littoral barrier (Figure 1).

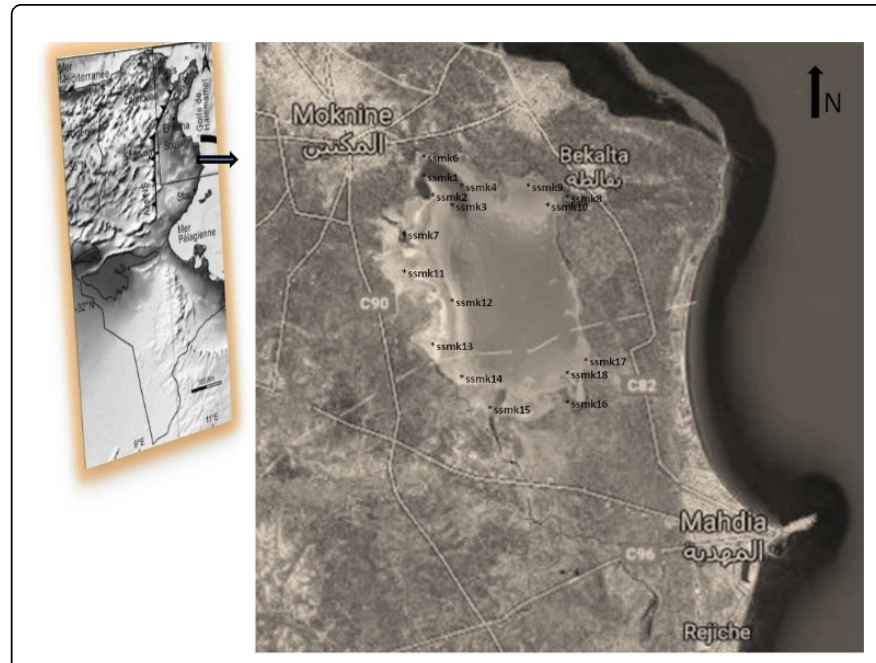

Figure 1: The Moknine sabkha, between Mahdia (Southeast) and Moknine (Northwest), is separated from the Mediterranean Sea by a 4-6 km wide littoral barrier

This type of endorheic depression, commonly found in Tunisia and on the sahelian platform, results from Quaternary tectonic events. The sabkha was formed by the subsidence of post-Villafranchian monoclinal and synclinal zones. It is roughly diamond shaped because of combined faults and calcareous cliffs up to $4 \mathrm{~m}$ high on the northern, eastern and southern edges. The sabkha, with a total area of ca. $50 \mathrm{~km}^{2}$, is devoid of obvious relief but slightly slopes eastward and, to a lesser extent, northward. Thus, the bottom is ca. $9 \mathrm{~m}$ below sea level in the eastern part and only $4 \mathrm{~m}$ below sea level in the southwestern part [8].

Examination of a large set of surface sediments [5,6] indicated a progressive decrease in particle size, especially for the west and southwest areas, from the periphery to the centre of the sabkha. Peripheral surface samples are therefore sandy $(2000-50 \mu \mathrm{m})$, while the samples from intermediate locations correspond to mixtures of silt $(50-2 \mu \mathrm{m})$ and sand, and central samples to mixtures of clay $(<2 \mu \mathrm{m})$ and silt. These studies also indicated that the sediments of the sabkha are exclusively of lacustrine origin and no marine influence was observed, as confirmed by the presence of shells of gastropods corresponding to typical continental species [5].

\section{Generality}

Autumn and winter are the rainy seasons, when the sebkha is partly flooded to a maximum water depth of ca. $3 \mathrm{~m}$ in the central and eastern parts, whereas the western part remains emerged. There is almost no rain in summer $30^{\circ} \mathrm{C}$, a large part of the sabkha being dry then. A wastewater treatment plant was introduced on the northwest edge in 1983. Domestic and industrial (textile and pottery works) wastewater, ca. $3300 \mathrm{~m}^{3}$ per day, is bioepurated. Water at the outlet of the plant contains some sludge, and analysis of organic and inorganic components [5] showed the following concentrations ( $\mathrm{mg} / \mathrm{l})$ : dissolved organic carbon (250), nitrate (9), ammonium (17) and phosphate (15). Owing to the resulting flow of treated water discharged to the sabkha, part of the northwest zone remains flooded even in summer. 
Moknine sebkha receives water mainly through precipitation and water from a catchment area estimate to be about $850 \mathrm{~km}^{2}$. The sebkha loses water only through evaporation due to its endorheic nature [7].

\section{Samples}

Surface sediments were collected by shovel in steel. The sediments were immediately wrapped in $\mathrm{Al}$ foil and kept frozen until analysis. Sections were homogenised and a part was directly dried at $40^{\circ} \mathrm{C}$ for TOC measurement on aliquots. The remainder was submitted to wet sieving to eliminate coarse debri. The $<63 \mu \mathrm{mm}$ fraction was dried at $40^{\circ} \mathrm{C}$ and used for lipid extraction, and hydrocarbon isolation and analysis. The overlying cyanobacterial mat carefully separated from the underlying sediment and also dried at $40^{\circ} \mathrm{C}$.

\section{Organic carbon}

TOC was determined using coulometry with a Coulomat $702 \mathrm{SO} /$ CS (Ströhlein) and 30-40 mg dry sediment for OM-rich samples and 80-100 mg for OM-poor samples. Aliquots were decarbonated with 2 $\mathrm{N} \mathrm{HCl}$ (at room temperature for limestone removal and at $60^{\circ} \mathrm{C}$ overnight for dolomite removal) before being combusted at $1300^{\circ} \mathrm{C}$.

\section{Extraction and analysis for lipid biomarkers}

Dry sediment or cyanobacterial mat samples were extracted with dichloromethane $(250 \mathrm{ml}$ for $20 \mathrm{~g})$ for $18 \mathrm{~h}$ at $50^{\circ} \mathrm{C}$ using a soxhlet apparatus. In addition to lipid components, the extracts contained large amounts of sulfur. For sulfur removal, the extracts were first concentrated under vacuum to ca. $2 \mathrm{ml}$ and eluted with dichloromethane from a column containing freshly prepared $\mathrm{Cu}-\mathrm{Zn}$ amalgam. The purified extracts were dried (solvent removal under vacuum) and weighed for quantification. F1 fraction was separated from the total lipid fraction using column chromatography (Pasteur pipettes filled with 60 mesh silica gel, elution with $5 \mathrm{ml}$ nhexane for F1 and weighed after solvent evaporation under vacuum.

The F1 apolar fraction containing the n-alkanes was dried with N2 and redissolved in heptane. GC analysis of the hydrocarbon fractions were performed using: a HP 5880A series gas chromatograph with a 30 m $0.25 \mathrm{~mm}$ i.d. SP 2100 column, programmed from $100^{\circ} \mathrm{C}$ to $300^{\circ} \mathrm{C}$ (held $10 \mathrm{~min}$ ) at $4^{\circ} \mathrm{C} / \mathrm{min}$, He as carrier gas, injector temperature $25^{\circ} \mathrm{C}$ and detector temperature $300^{\circ} \mathrm{C}$ GC-MS analysis was performed using an Agilent Technologie $6890 \mathrm{~N}$ gas chromatograph (same column and chromatographic conditions as above) coupled to an Agilent 5973 Network mass spectrometer (electron ionisation at $70 \mathrm{eV}$, cycle time $2.24 \mathrm{~s}$, range, $\mathrm{m} / \mathrm{z} 35-600)$. The relative abundances of $\mathrm{n}$-alkanes were determined by way of peak integration in the GC traces [corrected for the hump when an unresolved complex mixture (UCM) was present] and by integration of peaks in $\mathrm{m} / \mathrm{z} 57$ and 71 chromatograms for samples with no significant UCM. Quantification of the target compounds was determined using the hexatriacontane (C36) as internal standard. sterane and hopane relative abundances were determined by integration of peaks in $\mathrm{m} / \mathrm{z} 191$ and 217/218.

\section{Result and Discussion}

The emerged area represent the sediments in the western and southwestern parts of the sabkha ( $4 \mathrm{~m}$ below sea level). This zone is permanently emerged and represents the control area for this study. Sediment is composed essential by sandy facies. The lowest mass and OC fluxes occurred in southwestern $(<1 \%)$, EOM not exceed $9 \% \mathrm{OC}$ in average and the hydrocarbon fractions (F1) is about 3-4\%EOM (tab.1). Such features are thought to reflect permanent emersion and desiccation which result in extensive oxidative degradation of the OM [44-47]. There is a low density of Salicornia arabica.

The submerged area includes the northeast area near the treatment wastewater plant (CO: 0.91-2.19, EOM 6\%-26\%, F1 0.47-7.86\%), the northwest area, the marshy area and the center of the sebkha. The northwest area, ca. $6 \mathrm{~m}$ below sea level is influenced by treated water discharged from the wastewater treatment plant. As a result, the zone is permanently flooded, but with a weak water depth of only ca. $10 \mathrm{~cm}$ in summer. This zone is more rich organic matter than the emerged zone (tab). The northwest zone is covered with a dense and thick (ca. 3 $\mathrm{cm})$ cyanobacterial mat. This area is directly influenced by discharge from the Soltane Oued (CO: 4.9\%, EOM: 9\%CO, F1: 2.67\%EOM). The vegetation in the zone is dominated by cyanobacterial mats along with some reed (Phragmites sp.) clumps. The marshy eastern area of the sabkha, ca. $8 \mathrm{~m}$ below the sea level, is permanently inundated, with a maximum water depth of a few $m$ (CO: 1.13-1.74, EOM: $2-49 \%$ CO and F1: $0.6-3.7 \%$ EOM). The center of the sebkha ca $9 \mathrm{~m}$ below the sea level, is inundated in autum, winter and spring. In summer the halite deposition is about $30 \mathrm{~cm}$ after water evaporation (CO: $0.51-0.79 \%$, EOM: $1-22 \% \mathrm{CO}, \mathrm{F} 1:<7 \% \mathrm{EOM})$. The center of sebkha is devoid of vegetation.

\section{n-alkanes}

A bimodal distribution with maxima of comparable intensity at C18-C19 on one hand and at C25 on the other characterize sample in emerged area. The distribution of the lower molecular weight (LMW $<$ nC22) show no odd or even carbon predominance. Such a distribution indicates a bacterial origin. High molecular weight (HMW $>$ C22), predominantly odd numbered, C23-C33 n-alkanes with a maximum usually at $\mathrm{C} 27, \mathrm{C} 29$ or C31 are typical for epicuticular waxes of higher plant [7]. The long chain, C24-C33, n-alkanes exhibit a significant odd/even predominance (Figure 2).

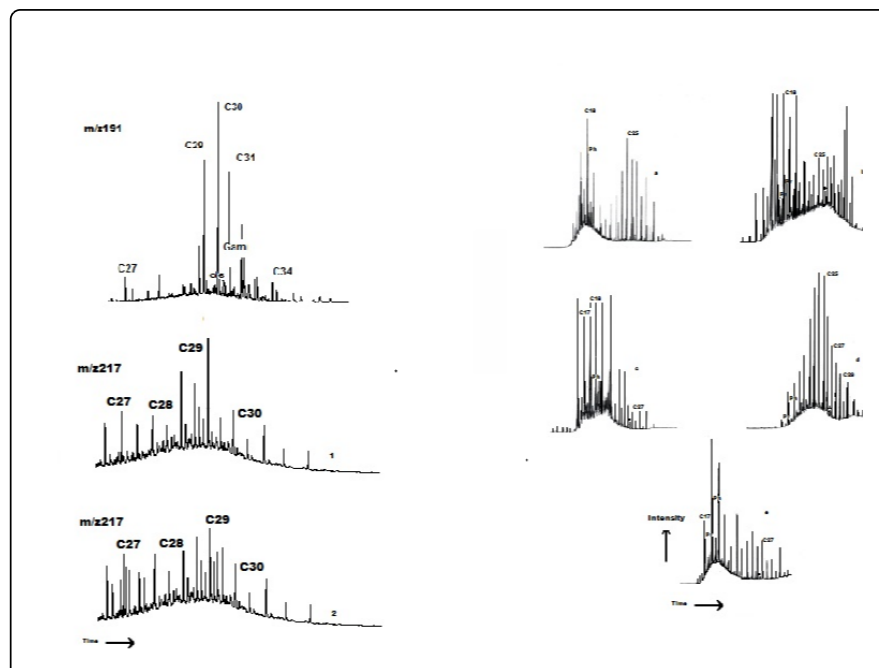

Figure 2: More distributions of n-alkanes were described the submerged area.

A bimodal $\mathrm{n}$-alkane distribution (Figure 2) with a maximum at $\mathrm{C} 17$ and a wide, bell-shaped, maximum in the $\mathrm{C} 22-\mathrm{C} 27$ range characterized the zone influenced by wastewater plant. The alkanes in 
Page 4 of 7

cyanobacterial mat extracts commonly exhibit a rather complex distribution. The maximum between C16 and C20 (LMW $<$ C22), with no significant odd or even predominance, reflects bacterial and cyanobacterial contributions [45]. For the higher molecular weight (HMW $>$ C20) compounds, the complex distribution is probably a result of contributions from alkanes from higher plants along with a moderate bacterial degradation for these long chain compounds.

In the northwest are, the silty/ sandy facies, show a unimodal moderately degraded waxy hydrocarbons from higher plants. The latter should originate from detritus discharged distribution with maxima at $\mathrm{C} 18-\mathrm{C} 20$ and some odd/even predominance for the long chain C25-C31 components (Figure 2). This distribution reflects a major contribution from alkanes of bacterial origin, along with a substantial contribution from the Soltane Oued that directly influences the ssm7 area (Figure 1) and from the Phragmites growing in the area. However, the former source should predominate since the alkanes produced by Phragmites show maxima at C27 and C29 [46,47] whereas these two compounds are not especially abundant here.

The marshy area shows cyanobacterial mats and a dense vegetation of halophilic plants, mostly composed of bushes of Zygophylum album and Atripex inflate (angiosperm) show a bell-shaped distribution from $\mathrm{C} 20-\mathrm{C} 32$, with no odd or even predominance, maximizing at $\mathrm{C} 23-$ C25 (Figure 2). On the contrary, the shortest compounds, in the C15C18 range, show a substantial predominance of the odd numbered $\mathrm{C} 15$ and $\mathrm{C} 17 \mathrm{n}$-alkanes. Such a distribution indicates that cyanobacterial mat hydrocarbons conspicuously predominate over higher plant components.

The center of sebkha are composed only by clay facies covered by halite in summer. The n-alkanes exhibit roughly unimodal distributions, with a maximum in the $\mathrm{C} 16-\mathrm{C} 20$ range. There is also a substantial contribution of long chain components maximizing around $\mathrm{C} 22-\mathrm{C} 25$ and some odd predominance in the C27-C31 range (Figure 2). $\mathrm{n}-\mathrm{C} 17 / \mathrm{n}-\mathrm{C} 29$ ratio range between $0.2-0.66$ in emerge area and 1.83-5.3 in immerged area. $\mathrm{n}-\mathrm{C} 29$ is abundant in land plants and n$\mathrm{C} 17$ is prominent in marine organisms, the ratio of these two alkanes reflects the relative contributions of allochthonous and autochthonous hydrocarbons to the sediments [48]. Hydrocarbons molecular weight subdivide this environment in two areas one is characterized by the abundance of high plant and the other by the biomass living in the sebkha.

In surface sediment and cyanobacterial mats from submerged area a peak of squalane (isoprenoide in C30) was identified, often found in cyanobacterial mats [45,49-51] and a precursor for steroids and triterpenoids [52]. It has also been associated with biological processes such as heterotrophic decomposition and methanogenesis [53,54]. Thus, it is not possible to attribute a source for this compound at present [45].

The UCM considered to be the result of many coelutions of structurally complex isomers and homologues of branched and cyclic hydrocarbons is also present and range from C15 to C33 in unimodal or bimodal shape (Figure 2). The presence of a hump in the GC chromatograms is the sign of a petroleum input and/or the presence of biodegraded complex mixture of hydrocarbons [9] like in coastal marine environments sediments [15,55-57]. The lack of oil contamination in the samples was confirmed by looking for the presence and the configuration of steranes and hopanes in $\mathrm{m} / \mathrm{z} 217$ and 191 chromatograms.

\section{Indexes}

The NAR ratio was close to $1, \mathrm{CPI}$ range from 3 to 4 , ACL is about 28.5 and TMD varied between 3-5. All indexes are indicated a contribution from higher plant components and moderate bacterial degradation in emerged area (Table 1).

Sample taken near wastewater plant are characterized by the index values (CPI: 1.18-1.79, NAR: 0.7-0.78, TMD:0.7-0.9, ACL:27.21-28.55) which is agree with the major contribution of aliphatic hydrocarbons from the cyanobacterial. In the northwest, (CPI: 1.71, ACL: 27.21, TMD: 0.35, NAR: 0.78), marshy area (CPI: 1.05, ACL: 27.3, TMD:0.3, NAR: 0.75$)$ and center, indexes data prove that immerse zone is the dominated by the original biomass of the sebkha (cyanobacteria and bacteria).

Both CPI and ACL are obtained using the n-alkanes data derived from higher plants, therefore, CPI and ACL are expected to correlate [15]. In the present study, the correlation between the CPI and ACL values show that there is no correlation between CPI and ACL $(r=$ 0.023 in emerged area and 0.25 in submerged area); which may be attributed to the fact that both CPI and ACL were not from the same source of higher plant. It was also noted that when two (or more) nalkanes that are characterized by different values of ACL or CPI, their ratio values usually varies nonlinearly and disproportionately [15].

\section{Hopanes}

The m/z 191 mass chromatograms of the saturated hydrocarbon fractions of all the analyzed samples show moderate abundances of pentacyclic. Hopanoids are important biomarkers for indicating organic matter that was derived from bacteria [26]. Their composition and distribution are similar in most of the samples and mainly consist of $\mathrm{C} 27$ to $\mathrm{C} 34$. 17,21 $\beta(\mathrm{H})$-hopanes with $\mathrm{C} 29 \beta$ and $\mathrm{C} 30 \beta$ hopanes as major compounds in emerged and submerged areas. The configuration $17 \alpha(\mathrm{H}), 21 \beta(\mathrm{H})$ trishomohopane $(\mathrm{C} 33 \mathrm{H} 58)$ are detected only in sample SSM1, SSM2 and SSM6 taken in immerged area contaminated by respectively treated wastewater and untreated wastewater.

However, the relative abundance of C29 hopane is generally less than that of $\mathrm{C} 30$ hopane in most of the analyzed samples, with C29/C30 ratios ranging from 0.11 to 0.6 in emerged area and from 0.11-1.21 in immerged zone. The low ratio can be explained by mixed organic sources. C29 is more abundant in the edge and C30 in the center of the sebkha. The predominance of C30 hopane is often associated with clay sediment [58]. which is in agreement with the sediment facies of the Moknine sebkha.

The oleanane, which is an important land plant derived biomarker [3]. was identified in low proportion in samples taken in perephery, supporting the presence of terrigenous organic matter input in the sediments. Oleanane is a pentacyclic triterpene which is originate from angiosperm like zyggophylum album and salicornia Arabica more abundant in edge of the sebkha. $18 a(\mathrm{H})$-Oleanane is described that the bioindicator or ideal molecular fossil for tracking the angiosperm lineage because its relative presence and relative concentration (also called the oleanane index) in Cretaceous and Tertiary sediments.

Gammacerane is present in all the samples analysed. The proportion of C30 increase from the periphery to the edge of Moknine system indicating input of organic matter in highly saline aquatic environment. Gammacerane is widely believed to have been derived from tetrahymanol in bacterivorous ciliates living at the boundary of a 
Page 5 of 7

high-salinity water layer with an upper layer of less saline water [41]. The abundance of C30 indicates that the organic materials were originated mainly from hypersaline environments [39].

\section{Steranes}

The steranes are another biomarkers group which are derived from sterols more abundant in higher plants and algae and rare in prokaryotic organisms $[59,60]$. The relative proportions of the C27, C28 and C29 regular steranes in sediments might provide valuable paleoenvironmental information [43]. The abundance of the regular steranes (C27, C28 and C29) differ from emerged area and submerged one depending upon the type of organic matter input to the sediment (Figure 2). The compounds detected in surface sediments are ( $\beta \beta \mathrm{C} 27)$ cholestane and $(\beta \beta C 28)$ methylcholestane and ( $\beta \beta C 29)$ ethylcholestane. The most abundant tetracyclic component in the emerged area are C29. C27 and C28 are present in low proportion. The ratios of C27/C29-steranes are in the range of 0.52-0.87 (Table1) further indicating an abundance of organic matter with higher plant origin in all surface sediments from the moknine sebkha. The dominance of $\mathrm{C} 27$ steranes would indicate a preponderance of marine phytoplankton, whereas a dominance of $\mathrm{C} 29$ would indicate a strong terrestrial contribution, and C28 steranes might indicate a heavy contribution by lacustrine algae. C27 is more abundant in the submerged area than emerged area. However Volkman [59] subsequently noted that certain marine organisms contribute to C29 regular steranes. Also Nichols PD [61] observed that large amounts of C29 sterols are produced by marine diatoms during the spring bloom in freezing Antarctic waters. Therefore, these biomarker interpretations should be used with caution.

\begin{tabular}{|c|c|c|c|c|c|c|c|c|c|c|c|c|c|}
\hline references & OC & ЕОМ\%ОC & $\mathrm{F} 1(\mathrm{mg} / \mathrm{kg})$ & CPI & $\mathrm{ACL}$ & TAR & NAR & LMW/HMW & TMD & $\mathrm{Pr} / \mathrm{Ph}$ & $\mathrm{nC} 17 / \mathrm{nC} 29$ & C29/C30 & C27/C29 \\
\hline ssmk1 & 0.91 & 22 & 1370 & 1.63 & 28.55 & 0.11 & 0.7 & 0.9 & 0.79 & 1.73 & 4.21 & 1.21 & 0.87 \\
\hline ssmk2 & 1.22 & 26 & 1430 & 1.45 & 28.5 & 0.15 & 0.75 & 0.9 & 0.83 & 1.5 & 4.53 & 1.05 & 0.84 \\
\hline ssmk3 & 1.95 & 21 & 1470 & 1.46 & 28.45 & 0.12 & 0.71 & 0.9 & 0.79 & 1.7 & 3.75 & 0.98 & 0.82 \\
\hline ssmk4 & 1.52 & 23 & 1450 & 1.45 & 27.54 & 0.11 & 0.72 & 0.87 & 0.79 & 1.53 & 2.75 & 0.94 & 0.75 \\
\hline ssmk5 & 2.19 & 16 & 786 & 1.18 & 27.25 & 0.11 & 0.75 & 0.89 & 0.79 & 1.62 & 3.85 & 1.08 & 0.66 \\
\hline ssmk6 & 1.62 & 14 & 1900 & 1.39 & 28.1 & 0.24 & 0.71 & 0.89 & 0.9 & 1.45 & 5.3 & 0.76 & 0.66 \\
\hline ssmk7 & 4.90 & 19 & 2670 & 1.71 & 27.21 & 0.29 & 0.78 & 1.13 & 0.35 & 1.71 & 3.52 & 0.11 & 0.70 \\
\hline ssmk8 & 1.74 & 18 & 1630 & 1.59 & 27.15 & 0.27 & 0.8 & 1.1 & 0.75 & 0.71 & 1.94 & 0.97 & 0.78 \\
\hline ssmk9 & 1.13 & 19 & 1610 & 2.47 & 27.18 & 0.27 & 0.79 & 1.2 & 0.8 & 0.89 & 1.9 & 1.15 & 0.82 \\
\hline ssmk10 & 1.48 & 2 & 3700 & 3.69 & 28.55 & 0.29 & 0.78 & 1.05 & 0.69 & 0.38 & 1.83 & 0.98 & 0.87 \\
\hline ssmk11 & 0.50 & 6 & 2170 & 3.11 & 28.65 & 8.5 & 0.87 & 0.28 & 3.8 & 0.50 & 0.66 & 0.21 & 0.25 \\
\hline ssmk12 & 0.47 & 5 & 1150 & 3.65 & 28.45 & 9.11 & 0.9 & 0.3 & 4.2 & 0.50 & 0.45 & 0.15 & 0.37 \\
\hline ssmk13 & 0.52 & 4 & 1040 & 2.40 & 28.52 & 9.2 & 0.83 & 0.35 & 4.2 & 0.4 & 0.48 & 0.25 & 0.48 \\
\hline ssmk14 & 0.60 & 12 & 800 & 3.28 & 28.48 & 8.5 & 0.8 & 0.28 & 3.8 & 0.38 & 0.52 & 0.6 & 0.18 \\
\hline ssmk15 & 0.46 & 12 & 1090 & 3.45 & 28.6 & 9.4 & 0.9 & 0.32 & 4.3 & 0.25 & 0.2 & 0.11 & 0.15 \\
\hline ssmk16 & 0.74 & 8 & 910 & 4.00 & 28.65 & 8.45 & 0.82 & 0.15 & 3.8 & 0.32 & 0.23 & 0.18 & 0.38 \\
\hline ssmk17 & 0.86 & 12 & 1300 & 3.51 & 28.5 & 7.25 & 0.75 & 0.12 & 3 & 0.30 & 0.28 & 0.45 & 0.24 \\
\hline ssmk18 & 0.99 & 6 & 790 & 3.24 & 28.52 & 9.75 & 0.92 & 0.2 & 5 & 0.20 & 0.34 & 0.6 & 0.41 \\
\hline
\end{tabular}

Table1: organic carbon and hydrocarbon parameters in surface sediments from Moknine sebkha OC: total organic carbon , EOM: total extract hydrocarbon, F1: aliphatic hydrocarbon fraction, CPI: Carbon preference index, TMD: Terrigenous Marine Discriminant, NAR: Natural n-alkane ratio, ACL, LMW/HMW, Pr: pristane, Phytane C29/C30 hopane, C27/C29 steranes, nC17/nC29 alkanes.

\section{Conclusion}

The biomarkers study in the surface sediment from the evaporate system of Moknine reveled the presence of many hydrocarbons sources reflected by the different distribution mode of $n$-alkanes. The essential sources is cyanobacteria and another bacteria characteristic of highly saline environment. The high plant dominate the edge of the sebkha and the emerged area where the facies is sand or sand-slity. All index prove the mixed origin of Moknine sebkha OM. ACL index indicate that about 150 years $(1 \mathrm{~mm} /$ year of sediment deposit in the sebkha), the climate is arid in this region.

hydrocarbons in the moknine system are mostly derived from the biomass. you not find an indice of petrol infiltration in the phreatic nape of Moknine. OM is immature in early diagenesis. halophyte plant can gener biopetrol like the pilote station in emirate. UCM is not indicate pollution but is the result of bacteria activities. In order to more prove the biogenic origin of hydrocarbons in the sebkha it is 
suggested to analyze the alkenes because are not present in crude oils. Alkenes generally have a biogenic origin although they may be found in refined petroleum products. They are sometimes present in large amounts in many organisms such as algae, phytoplankton, crustacean. Most frequently alkenes found in sediments are mono and poly unsaturated linear alkenes, phytadienes and squalene.

\section{References}

1. Tissot BP, Welte DH (1984) Petroleum Formation and occurrence: A new approach to oil and gas exploration (2n dedn), Springer - Verlag, Berlin, p699.

2. Philp RP (2004) Formation and Geochemistry of Oil and Gas. In: Holland HD, Turekian KK (editors). Treatise on Geochemistry, Mackenzie, Elsevier, Amsterdam, p425.

3. Peters KE, Walters CC, Moldowan JM (2005) Biomarkers and Isotopes in Petroleum Systems and Earth History ,The Biomarker Guide, (2ndedn) Cambridge University Press, United Kingdom.

4. Chairi R, Belayouni H (1999) Etude de la matière organique dans les sédiments de la sebkha de Moknine. Acte du 2ème Colloque International sur l'eau et l'environnement Agadir p 206.

5. Chairi R, Belayouni H (2004) Characterization of the organic matter in the surface sediments from the Moknine sebkha. Proceedings of the 5th Tunisia Japan Symposium on Culture, Science and Technology.

6. Chairi R (2005) Etude du remplissage sédimentaire d'un système hypersalin de la Tunisie orientale au cours du quaternaire récent : la sebkha de Moknine. Quaternaire 16: 107-117.

7. Raja C, Sylvie D, Saadi A, Claude L (2010) Sediment cores representative of the contrasting environments in the salt flats of the Moknine continental sabkha (Eastern Tunisia): sedimentology, bulk features of organic matter, alkane sources and alteration. Organic geochemistry 41: 637-652.

8. Chairi R, Belayouni H (2001) Résultats préliminaires de létude de la matière organique dans les sediments récents de la sebkha de Moknine. Rapport de la commission internationale en mer Méditerranéenne, 36: p117.

9. Mille G, Asia L, Guiliano M, Malleret L, Doumenq P (2007) Hydrocarbons in coastal sediments from the Mediterranean Sea (Gulf of Fos area, France) Mar Pollut Bul 54: 566-575.

10. Meyers PA (2003) Application of organic geochemistry to paleolimnological reconstruction: a summary of examples from the Laurentian Great Lake. Org Geochem 34: 261-289.

11. Syakti AD, Hidayati NV, Hilmi E, Piram A, Doumenq P (2013) Source apportionment of sedimentary hydrocarbons in the Segara Anakan Nature Reserve, Indonesia. Mar Pollut Bull 74: 141-148.

12. Azis MY, Asia L, Piram A, Buchari B , Doumenq P, et al. (2016) Aliphatics hydrocarbon content in surface sediment from Jakarta Bay, Indonesia. 10th Joint Conference on Chemistry. IOP Conf. Series: Materials Science and Engineering.

13. Poynter J, Eglinton G (1990) Molecular Composition of Three Sediments from Hole 717C: the Bengal Fan, College Station. TX Ocean Drilling Program.

14. Poynter J, Farrimond P, Robinson N, Eglinton G (1989) Aeolian-derived higher plant lipids in the marine sedimentary record: links with palaeoclimate, in: Paleoclimatology and Paleome-10 teorology: Modern and Past Patterns of Global Atmospheric Transport. In: Leinen M, Sarnthein M, Springer, Netherlands. 435-62.

15. Jeng WL (2006) Higher plant n-alkane average chain length as an indicator of petrogenic hydrocarbon contamination in marine sediments Mar Chem 102: 242-51.

16. Bai Y, Fang X, Nie J, Wang Y, Wu F (2009) A preliminary reconstruction of the paleoecological and paleoclimatic history of the Chinese Loess Plateau from the application of biomarkers. Palaeogeogr Palaeocl 271: 161-169.
17. Hughen KA, Eglinton TI, Xu L, Makou M (2004) Abrupt tropical vegetation response to rapid climate changes. Science 304: 1955-59.

18. Yamamoto S, Kawamura K, Seki O, Meyers PA, Zheng Y, et al. (2010) Environmental influences over the last 16ka on compound-specific $\delta 13 \mathrm{C}$ variations of leaf wax n-alkanes in the Hani peat deposit from northeast China. Chem Geol 277: 261-68.

19. Zhang, Z, Zhao M, Eglinton G, Lu H, Huang CY (2006) Leaf wax lipids as paleovegetational and paleoenvironmental proxies for the Chinese Loess Plateau over the last 170kyr. Quaternary Sci Rev 25: 575-594.

20. Zhou W, Zheng Y, Meyers PA, Jull, AJT, Xie S (2010) Postglacial climatechange record in biomarker lipid compositions of the Hani peat sequence, Northeastern China. Earth Planet Sc Lett 294: 37-46.

21. Castañeda IS, Werne JP, Johnson TC, Filley TR (2009) Late Quaternary vegetation history of southeast Africa: the molecular isotopic record from Lake Malawi. Palaeogeogr Palaeocl 275: 100-112.

22. Wang M, Zhang W, Hou J (2015) Is average chain length of plant lipids a potential proxy for vegetation, environment and climate changes? Biogeosciences Discuss 12: 5477-5501.

23. Cooper JE, Bray EE (1963) A postulated role of fatty acids in petroleum formation. Geochimica Et Cosmochimica Acta 27:1113-27.

24. Cranwell PA (1973) Chain legth distribution of n-alkanes from lake sediemnts in relation to postglacial environmental change. Freshw Biol 3: 259-265.

25. Volkman JK, Holdsworth DG, Neill GP, Bavor HJ (1992) Identification of natural, anthropogenic and petroleum-hydrocarbons in aquatic sediments. Sci Total Environ 112: 203-219.

26. Ourisson G, Albrecht P (1992) Hopanoids 1. Geohopanoids-the most abundant natural products on earth. Acc Chem Res 25: 398-402.

27. Ourisson G, Rohmer M, Poralla K (1987) Microbial lipids betrayed by their fossils. Microbiol Sci 4: 52-57.

28. Mackenzie AS, Brassell SC, Eglinton G, Maxwell JR (1982) Chemical fossils: the geological fate of steroids. Science 217: 491-509.

29. Manan N, Raza M, Yuh YS, Theng LW, Zakaria MP (2011) Distribution of petroleum hydrocarbons in aquaculture fish from selected locations in the Straits of Malacca,Malaysia. World App Sci J 14: 14-21.

30. Bieger T, Hellou J, Abrajano TA (1996) Petroleum biomarkers as tracers of lubricating oil contamination. Mar Pollut Bull 32: 270-4.

31. Neff JM, Durell GS (2012) Bioaccumulation of petroleum hydrocarbons in arctic amphipods in the oil development area of the Alaskan Beaufort Sea. Integr Environ Assess Manag 8: 301-19.

32. Meyers PA, Ishiwatari R (1993) Lacustrine organic geochemistry an overview of indicators of organic matter sources and diagenesis in lake sediments. Org Geochem 20: 867-900.

33. Qu W, Xue B, Su C, Wang S (2007) Evaluation of biogenic and anthropogenic inputs of aliphatic hydrocarbons to Lake Taihu sediments using biomarkers. Hydrobiologia 581: 89-95.

34. Xiong Y, Wu F, Fang J, Wang L, Li Y, Liao H (2010) Organic geochemical record of environmental changes in Lake Dianchi, China. J Paleolimnol 44: 217-31.

35. Prince RC, Elmendorf DL, Lute JR, Hsu CS, Haith CE, Senius JD 1(994) $17 \alpha(\mathrm{H})-21 \beta(\mathrm{H})$-hopane as a conserved internal marker for estimating the biodegradation of crude oil. Environ Sci Technol 28: 142-145.

36. Kleeman MJ, Riddle SG, Robert MA, Jakober CA (2007) Lubricating oil and fuel contributions to particulate matter emissions from light-duty gasoline and heavy-duty diesel vehicles. Environ Sci Technol 42: 235-42.

37. Schauer JJ, Kleeman MJ, Cass GR, Simoneit BR (1999) Measurement of emissions from air pollution sources. 2. C1 through C30 organic compounds from medium duty diesel trucks. Environ Sci Technol 33: 1578-87.

38. Schauer JJ, Kleeman MJ, Cass GR, Simoneit BR (2002) Measurement of emissions from air pollution sources. 5. C1-C32 organic compounds from gasoline-powered motor vehicles. Environ Sci Technol 36: 1169-80.

39. Peters KE. and Moldowan JM (1993) The biomarker guide. Interpreting Molecular Fossils in Petroleum and ancient sediments. Prentice Hall, Englewood Cliffs, New Jersey, USA, p363. 
Citation: Chairi R (2018) Biomarkers on Sediments in a Highly Saline Aquatic Ecosystem: Case of the Moknine Continental Sebkha (Eastern Tunisia). J Coast Zone Manag 21: 463. doi:10.4172/2473-3350.1000463

Page 7 of 7

40. Summons RE, Walter MR (1990) Molecular fossils and microfossils of prokaryotes and protists from proterozoic sedeimnts. Am J Sci 290A: 212-244.

41. Damste JSS, Kenig F, Koopmans MP, Koster J, Schouten S, et al. (1995) Evidence for gammacerane as an indicator of water column stratification. Geochimica et Cosmochimica Acta 59: 1890- 1900

42. Brock JJ, Summons RE (2004) Sedimentary Hydrocarbons, Biomarkers for Early Life. In: Heinrich H, Turekian K (editors). Treatise on geochemistry (2ndedn), Elsevier, Amsterdam, Netherlands pp 61-103.

43. Jeon CW (2012) Characteristic Investigation for Source and Degradation of Crude Oil Using Steranes and Terpanes biological Markers. Applied Chemistry 16: 49-52.

44. Salmon V, Derenne S, Lallier-Vergès E, Connan J, Kahn-Harari A, et al (2003) Origin and compositional difference in organic matter abundance and oil potential of cherty and clayey Cenomanian black levels in the Umbria-Marche basin (Italy). Organic Geochemistry 34: 1237-1245.

45. Jungblut AD, Allen MA, Burns BP, Neilan BA (2009) Lipid biomarker analysis of cyanobacteria-dominated microbial mats in meltwater ponds on the McMurdo Ice Shelf, Antarctica. Org Geochem 40: 258-269.

46. Ogura K, Machihara T and Takada H (1990) Diagenesis of biomarkers in Biwa Lake sediments over 1 million years. Org. Geochem 16: 805-13

47. Ficken KJ, Street-Perrot FA, Perrot RA, Swain DL, Olago DO, et al. (1998) Glacial/interglacial variations in carbon cycling revealed by molecular and isotope stratigraphy of Lake Nkunga, Mt Kenya, East Africa. Org Geochem 29: 1701-19.

48. Massone CG, Wagener A, Abreu HM, Veiga A (2013) Revisiting hydrocarbons source appraisal in sediments exposed to multiple inputs. Marine Pollution Bulletin 73: 345-354.

49. Rontani JF, Volkman JK (2005) Lipid characterization of coastal hypersaline cyanobacterial mats from the Camargue (France). Org Geochem 36: 251-272.

50. Fang J, Chan O, Joeckel RM, Huang Y, Wang Y, et al. (2006) Biomarker analysis of microbial diversity in sediments of a saline groundwater seep of Salt Basin, Nebraska. Organic Geochemistry 37: 912-931.
51. Ladygina N, Dedyukhina EG, Vainshtein MB (2006) A review on microbial synthesis of hydrocarbon. Process Biochemistry 41: 1001-14.

52. Boon JJ, Burlingame AL (1981) organic geochemical studies of solar lake laminated cyanobacterial mats. Advences in Geochemestry 207-227.

53. Dobson G, Ward DM, Robinson N, Eglinton G (1988) Biogeochemistry of hot spring environments: extractable lipids of a cyanobacterial mat. Chemical Geology 68: 155-79.

54. Grimalt JO, De Wit R, Teixidor P, Albaigés J (1991) Lipid biogeochemistry of Phormidium and Microcoleus mats. Advances in Geochemistry 19: 509-530.

55. Matsumoto G (1983) Comparative study on organic constituents in polluted and unpolluted inland aquatic environments. Organic carbon and hydrocarbons in sediments. Water Res 17: 823-830.

56. Tolosa I, Bayona JM, Albaiges J (1996) Aliphatic and polycyclic aromatic hydrocarbons and sulfur/oxygen derivatives in Northwestern Mediterranean sediments: spatial and temporal variability, fluxes, and budgets. Environ. Sci Technol 30: 2495-2503.

57. Tolosa I, Mesa-Albernas M, Alonso-Hernandez CM (2009) Inputs and sources of hydrocarbons in sediments from Cienfuegos bay, Cuba. Marine Pollution Bulletin 58: 1624-34.

58. Gürgey K (1999) Geochemical characteristics and thermal maturity of oils from the Thrace Basin (northwestern Turkey) and western Turkmenistan. Journal of Petroleum Geology 22: 167-189.

59. Volkman JK (1986) A review of sterol markers for marine and terrigenous organic matter. Organic Geochemistry 9: 83-99.

60. Volkman JK (2003) Sterols in microorganisms. Applied Microbiology and Biotechnology 60: 495-506.

61. Nichols PD, Palmisano AC, Rayner MS, Smith GA, White DC (1990) Occurrence of novel C30 sterols in Antarctic sea-ice diatoms communities during a spring bloom. Organic Geochemistry 15: 501-508. 